\title{
Resistance to Passion fruit woodiness virus in Transgenic Passionflower Expressing the Virus Coat Protein Gene
}

\author{
F. Trevisan and B. M. J. Mendes, Laboratório de Biotecnologia Vegetal, CENA/USP, 13400-970 Piracicaba, SP, \\ Brazil; S. C. Maciel, Dept. de Entomologia, Fitopatologia e Zoologia Agrícola, ESALQ/USP, 13418-900 Piracicaba, \\ SP, Brazil; M. L. C. Vieira, Dept. de Genética, ESALQ/USP, 13418-900 Piracicaba, SP, Brazil; L. M. M. Meletti, \\ Centro de Fruticultura, Instituto Agronômico, 13020-902 Campinas, SP, Brazil; J. A. M. Rezende, Dept. de Ento- \\ mologia, Fitopatologia e Zoologia Agrícola, ESALQ/USP, 13418-900 Piracicaba, SP, Brazil
}

\begin{abstract}
Trevisan, F., Mendes, B. M. J., Maciel, S. C., Vieira, M. L. C., Meletti, L. M. M., and Rezende, J. A. M. 2006. Resistance to Passion fruit woodiness virus in transgenic passionflower expressing the virus coat protein gene. Plant Dis. 90:1026-1030.

We report the use of the coat protein $(\mathrm{CP})$ gene from Passion fruit woodiness virus (PWV) to produce resistant transgenic plants of yellow passion fruit. A full-length $\mathrm{CP}$ gene from a severe PWV isolate from the state of São Paulo, Brazil (PWV-SP) was cloned into pCAMBIA 2300 binary vector, which was further introduced into Agrobacterium tumefaciens strain EHA 105. Leaf disks were used as explants for transformation assays, e.g., 2,700 and 2,730 disks excised from plants from the Brazilian cultivars IAC-275 and IAC-277, respectively. In vitro selection was performed in kanamycin. After transferring to the elongation medium, 119 and 109 plantlets of IAC-275 and IAC-277, respectively, were recovered. Integration of the PWV CP gene was confirmed in seven of eight plants evaluated by Southern blot analysis, showing different numbers of insertional events for the CP gene. Three transgenic plants (T3, T4, and T7) expressed the expected transcript, but the $32 \mathrm{kDa}$ PWV CP was detected by Western blot in only two plants (T3 and T4). The results of three successive mechanical inoculations against the transgenic plants using three PWV isolates showed that the primary transformant T2 of IAC-277 was immune to all isolates.
\end{abstract}

Additional keywords: potyvirus, transgenic resistance

Yellow passionflower (Passiflora edulis Sims. f. flavicarpa Degener) has been widely grown in Brazil on approximately 36,000 ha. Virus diseases did not limit production of passionflower in Brazil until the 1970s, when a potyvirus identified as Passion fruit woodiness virus (PWV) was first detected in the state of Bahia (3). Sequence analysis of the coat protein (CP) determined that the Brazilian isolates of this potyvirus shared a higher identity (85\%) with Cowpea aphid borne mosaic virus (CABMV) than with PWV (68 to $76 \%)(17,21)$. As no official change in the nomenclature of the causal agent of passion fruit woodiness disease has been proposed in Brazil or published in the Eighth Report on Virus Taxonomy (6), it will be referred to as PWV.

PWV is currently found in all passion vines in Brazil, where it is the most economically important viral disease of this tropical fruit crop. The virus is transmitted

Corresponding author: J. A. M. Rezende

E-mail: jamrezen@esalq.usp.br

Accepted for publication 19 March 2006.

DOI: 10.1094/PD-90-1026

(C) 2006 The American Phytopathological Society in a nonpersistent manner by several aphid species that do not colonize passionflower. Besides reducing the productive life of an orchard from 36 to 18 months, the virus also causes significant loss of fruit yield and quality (8).

Control of PWV is very difficult. Planting of new orchards near old and abandoned infected vines, which can serve as sources of inoculum, and difficulty in controlling the virus vectors are the main factors explaining the rapid spread of the disease. Further, no sources of resistance to virus infection or tolerance to the disease have been found in cultivated yellow passion fruit germ plasm, and cross protection by pre-immunization with selected mild PWV strains did not offer protection against infection by more virulent strains (18). Presently, the only way to control the disease in Brazil is by means of cultural practices such as the use of healthy seedlings for transplanting, eliminating old infected orchards before starting new crops, no interplanting with leguminous species, which can harbor the virus, and roguing of diseased plants until 5 to 6 months after planting.

A recent alternative strategy to control plant virus diseases is the application of the pathogen-derived resistance concept (20), producing transgenic plants express- ing virus-derived genes or virus genome fragments. In this approach, the resistance can operate either by expression of the protein encoded by the transgene (proteinmediated) or by the transcript produced from the transgene (RNA-mediated) $(19,25)$. The viral gene most frequently used is the $\mathrm{CP}$ gene, which has been shown to be effective in preventing or reducing infection and disease caused by the homologous virus. Development of virusresistant cultivars for commercial application using this approach was reported for papaya and zucchini squash crops $(7,26)$. For the PWV-passion fruit pathosystem, Alfenas et al. (1) described the production of one resistant transgenic plant expressing a nontranslatable RNA corresponding to the $3^{\prime}$ region of the $N i b$ gene and the $5^{\prime}$ region of the $\mathrm{CP}$ gene derived from the genome of one CABMV Brazilian isolate. As resistance was strain specific, more transgenic lines are needed in order to obtain broader resistance.

Here we report the use of the PWV CP gene to produce transgenic passion fruit plants, using Agrobacterium tumefaciens as a vector. The plants were challenged by PWV by mechanical inoculation in the greenhouse, and the resistance level was evaluated.

\section{MATERIALS AND METHODS}

Vector construction and Agrobacterium cells transformation. A full-length $\mathrm{CP}$ gene from a severe PWV isolate from the state of São Paulo, Brazil (PWV-SP, GenBank Accession AY433950) was amplified by polymerase chain reaction (PCR). To this was introduced an ATG initiation codon, a $\mathrm{SacI}$ restriction site at the $5^{\prime}$ end, and a BamHI restriction site at the $3^{\prime}$ end. The complementary primers to the virus sequence including the initiation codon (italics) and the restriction sites (bold) were: PWV-P1 $=5^{\prime}$-G GAG CTC ATG TCT GAT G(G/A)A A(A/G)G GAC AA- $3^{\prime}$ and PWV-P2 $=5^{\prime}-\mathrm{G}$ GGA TCC TCA CTG CCC ATG CGT CAT-3'. The PCR product was cloned in the sense orientation driven by a strong artificial promoter consisting of duplicated $35 \mathrm{~S}$ from Cauliflower mosaic virus (CaMV) and the $35 \mathrm{~S}$ terminator. The expression cassette was cloned into pCAMBIA 2300 binary vector, renamed 2300-PWV (Fig. 1). The 
vector contains the $n p t \mathrm{II}$ selection gene and was introduced into A. tumefaciens strain EHA 105 using the freeze-thaw method (11). A. tumefaciens was cultivated in YEP solid medium (10 g peptone, $10 \mathrm{~g}$ yeast extract, $5 \mathrm{~g}$ sodium chloride, and 15 $\mathrm{g}$ agar per liter) containing kanamycin (100 mg liter ${ }^{-1}$ ) and rifampicin (50 mg liter $^{-1}$ ) for $48 \mathrm{~h}$. A single colony was then transferred to a 250-ml Erlenmeyer flask, with YEP liquid medium $(50 \mathrm{ml})$ supplemented with antibiotics and cultivated at $180 \mathrm{rpm}\left(28^{\circ} \mathrm{C}, 16 \mathrm{~h}\right)$. The bacterial suspension was centrifuged at $5,000 \times g$ $\left(15^{\circ} \mathrm{C}, 15 \mathrm{~min}\right)$ and resuspended in liquid MS medium (16) to achieve a bacterial concentration of $5 \times 10^{8} \mathrm{CFU} \mathrm{ml}^{-1}$.

Agrobacterium-mediated transformation of passionflower. Passionflower cvs. IAC-275 and IAC-277 cultivated at $27 \pm$ $1{ }^{\circ} \mathrm{C}$ were used for genetic transformation. Explants consisted of leaf disks $(6 \mathrm{~mm}$ diameter) collected from young leaves of 50- to 75-day-old seedlings. For asepsis, the leaves were treated with a sodium hypochlorite solution $(0.5 \%)$ for $15 \mathrm{~min}$, followed by three rinses with sterile distilled water. Explants were inoculated for 20 min with A. tumefaciens EHA 105 containing pCAMBIA 2300-PWV. After inoculation, the explants were blotted dry and transferred to MS medium supplemented with thidiazuron (TDZ; $0.25 \mathrm{mg}$ liter $\left.{ }^{-1}\right), \mathrm{AgNO}_{3}$ (4 mg liter ${ }^{-1}$, and acetosyringone $\left(100 \mu \mathrm{M} \mathrm{liter}^{-1}\right)$ for a 3-day cocultivation period at $24^{\circ} \mathrm{C}$. After cocultivation, explants were transferred to selection medium consisting of MS supplemented with $\mathrm{TDZ}, \mathrm{AgNO}_{3}$, kanamycin $\left(100 \mathrm{mg} \mathrm{liter}{ }^{-1}\right)$, and cefotaxime $(500 \mathrm{mg}$ liter $\left.^{-1}\right)$. Cultures were incubated in the dark for 6 to 8 weeks at $27^{\circ} \mathrm{C}$, then changed to a 16-h photoperiod $\left(63 \mu \mathrm{mol} \mathrm{m} \mathrm{m}^{-2} \mathrm{~s}^{-1}\right)$ at $27 \pm$ $1^{\circ} \mathrm{C}$. Developed shoots were transferred to Magenta box, covered with vented lids (Sigma Chemical Co., St. Louis, MO) containing elongation medium, i.e., MSM (15) supplemented with coconut water $(10 \%)$ and cefotaxime (500 mg liter $\left.{ }^{-1}\right)$, and incubated with a 16-h photoperiod for further plant development.

PCR and Southern blot analyses. Genomic DNA was extracted (5) from leaves of well-developed in vitro plantlets $(1 \mathrm{~cm}$ long). The presence of the PWV CP gene in the putative transgenic plantlets was detected by PCR using the PWV-P1 and PWV-P2 primers. The PCR protocol was: 30 to $50 \mathrm{ng}$ DNA, $100 \mu \mathrm{M}$ of each dNTP, $5 \mathrm{mM} \mathrm{MgCl}_{2}, 0.2 \mu \mathrm{M}$ of each primer, and 1 U Taq DNA polymerase (Promega, Madison, WI). Reactions were performed under the following conditions: $2 \mathrm{~min}$ at $94^{\circ} \mathrm{C}$ for the first denaturation, followed by 35 cycles of $45 \mathrm{~s}$ at $94^{\circ} \mathrm{C}, 1 \mathrm{~min}$ at $52^{\circ} \mathrm{C}$, and $1 \mathrm{~min}$ at $72^{\circ} \mathrm{C}$, with a final extension of $1 \mathrm{~min}$ at $72^{\circ} \mathrm{C}$. PCR products were analyzed by electrophoresis in $1 \%$ agarose gel at $2.5 \mathrm{~V} \mathrm{~cm}^{-1}$. PCR-positive plantlets were transferred to pots containing sterile substrate and acclimated to greenhouse conditions.

Southern blots were performed for PCRpositive plants to confirm genetic transformation and to estimate the number of insertional events. DNA was extracted from fully expanded leaves of acclimated plants using Plant DNAzol reagent protocol (Invitrogen, Carlsbad, CA). DNA (20 $\mu \mathrm{g}$ ) was digested with BamHI, which cuts the T-DNA once outside the PWV CP gene. Digested DNA was separated on $1 \%$ agarose gel by electrophoresis at $1 \mathrm{~V}$ $\mathrm{cm}^{-1}$ for about $16 \mathrm{~h}$. DNA was transferred to a positively charged nylon membrane (Hybond- $\mathrm{N}^{+}$, Amersham Biosciences, UK) and subsequently fixed by UV irradiation. A PCR-amplified fluoresceinlabeled (Gene Images Random Prime Labelling Module, Amersham Biosciences) fragment from the coding region of the PWV CP gene (850 bp) was used as a probe. Prehybridization, hybridization, washing, and detection were performed with Gene Images CDP-Star detection module (Amersham Biosciences) following the supplier's instructions.

Western blot. Tissue samples $(0.5 \mathrm{mg})$ of transgenic plants were ground in $500 \mu \mathrm{l}$ of dissociation buffer $(0.5 \mathrm{M}$ Tris- $\mathrm{HCl}, \mathrm{pH}$ $6.8,3.8 \%$ sodium dodecyl sulfate [SDS], $10 \% \beta$-mercaptoethanol, $0.1 \%$ bromophenol blue, and $19 \%$ glycerol) and boiled for $5 \mathrm{~min}$. The extracts were centrifuged $(5,000 \times g, 5 \mathrm{~min})$ and the dissociated proteins were separated in $12.5 \%$ poly- acrylamide gel electrophoresis (PAGE)SDS gel (12). Proteins were then transferred to nitrocellulose membrane (BioAgency, Brazil) using a Bio-Rad minitransblot apparatus. The membrane was blocked with $7.5 \%$ dry milk diluted in TBS buffer $(0.002 \mathrm{M}$ Tris, $\mathrm{pH} 7.4,0.15 \mathrm{M}$ $\mathrm{NaCl})$ for $30 \mathrm{~min}$ at room temperature. The membrane was incubated overnight $\left(4^{\circ} \mathrm{C}\right)$ with polyclonal antiserum against PWV $\mathrm{CP}$ diluted $1: 1,000$ in TBS $+7.5 \%$ dry milk. After four rinses with TBS $+0.05 \%$ Tween 20, the membrane was incubated (4 h) with alkaline phosphatase-conjugated anti-rabbit IgG (Sigma A8025) and diluted 1:32,000 in TBS. After five rinses with TBS-Tween, it was incubated with the substrate NBT/BCIP prepared in its buffer (4). The reaction was stopped by rinsing the membrane in distilled water.

Northern blot. Total RNA was isolated from leaves $(100 \mathrm{mg})$ collected from acclimated transgenic plants using TRIzol reagent protocol (Invitrogen). A nontransgenic inoculated plant and a nontransgenic healthy plant were used as positive and negative controls, respectively. Fifteen micrograms of RNA of each sample were separated in a $0.8 \%$ agarose gel with formaldehyde and transferred onto a nylon membrane (Hybond, Amersham Biosciences). Hybridization was performed using the fluorescein-labeled probe prepared from the PCR-amplified PWV CP fragment, as described for the Southern blot assay.

Plant inoculation with PWV. The transgenic passion fruit plants were multiplied by stem cuttings under greenhouse conditions. Plants at the stage of four to five leaves were mechanically inoculated with PWV isolates from the states of São Paulo (PWV-SP), Rio de Janeiro (PWV$\mathrm{RJ})$, and Ceará (PWV-CE), separately. These isolates are similar in severity of symptoms induced on passion fruit plants. For inoculation, two leaves of each plant were dusted with Carborundum and rubbed with a 50- $\mu$ l aliquot of 1:200 $(\mathrm{wt} / \mathrm{vol})$ diluted inoculum per leaf. The inoculum consisted of fresh leaves from PWV-infected passionflowers ground in $0.02 \mathrm{M}$ phosphate buffer ( $\mathrm{pH}$ 7.0) contain-

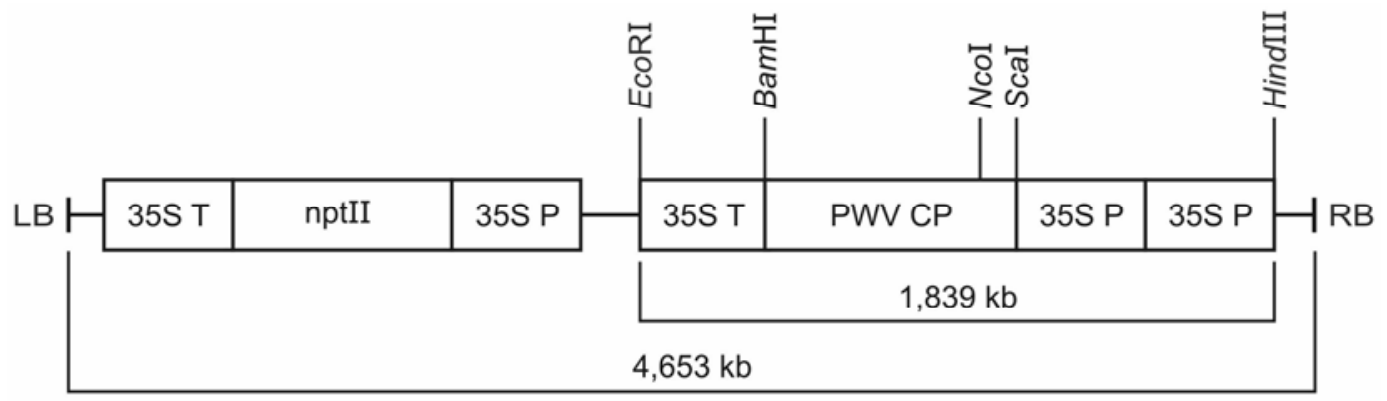

Fig. 1. Schematic representation of the expression cassette of the pCAMBIA 2300-Passion fruit woodiness virus-coat protein gene (PWV-CP). LB: left border; RB: right border; 35S P: Cauliflower mosaic virus (CaMV) 35S promoter; 35S T CaMV 35S terminator; nptII: neomycin phosphotransferase II gene; PWV-CP: PWV coat protein gene. 
ing $0.02 \mathrm{M}$ sodium sulfite. Fifteen days later, two newer expanded leaves of the same plant were reinoculated with the same volume of inoculum diluted 1:100 (wt/vol). A third inoculation, with $200 \mu \mathrm{l}$ of inoculum diluted 1:50 (wt/vol) per leaf, was done 15 days later. Healthy nontransformed passionflowers were inoculated in the same way at each inoculation period. Disease resistance was assessed by comparing the rate of symptom development (mosaic, leaf distortion, and reduction) and severity on new growth of transgenic and nontransgenic plants.

\section{RESULTS}

Genetic transformation and plant characterization. Genetic transformation with A. tumefaciens was achieved in passionflower cultivars IAC-275 and IAC277. The incubation of explants in the dark favored shoot development. For IAC-275, 2,700 explants were inoculated with $A$. tumefaciens and 260 shoots developed in the selection medium. After transferring the shoots to elongation medium, 119 plantlets grew, but only two were identified as PCR positive for the PWV CP gene, a genetic transformation efficiency of

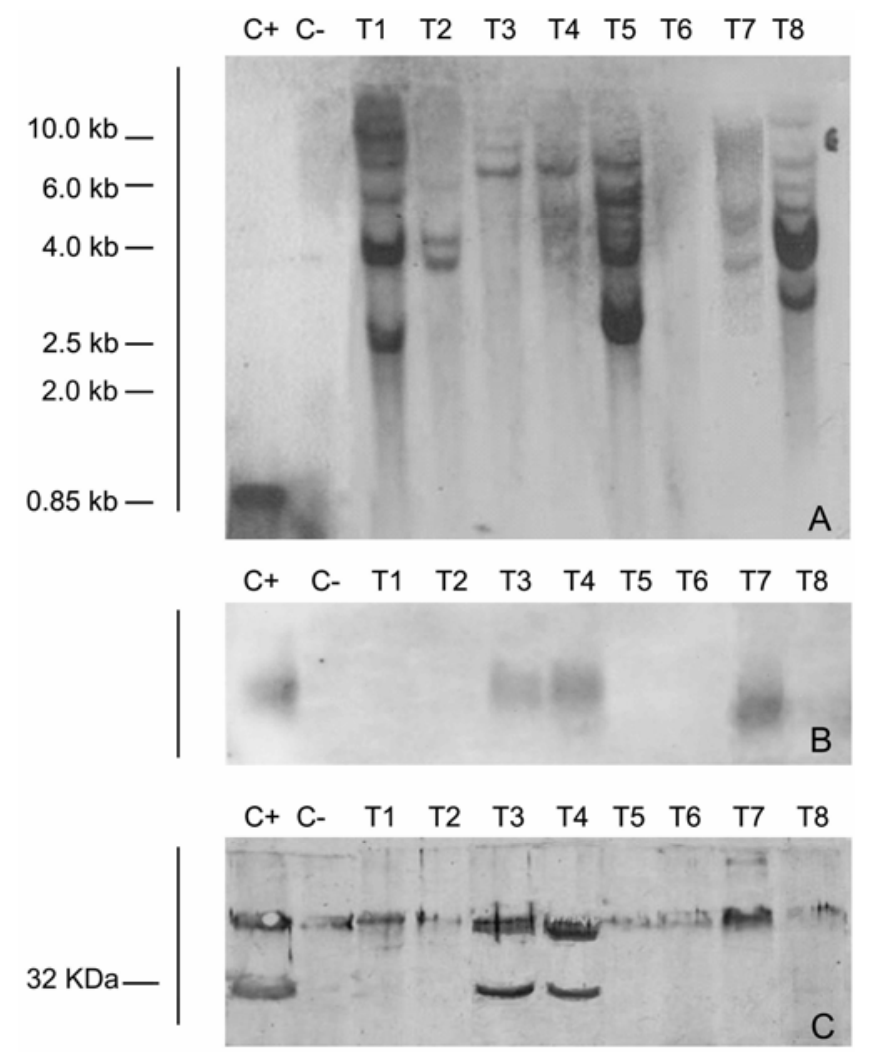

Fig. 2. Molecular characterization of passion fruit regenerated plants. A, Southern blot. C+: pCAMBIA 2300-Passion fruit woodiness virus-coat protein gene; C-: a nontransformed plant. B, Northern blot. C+: nontransgenic inoculated plant; $\mathrm{C}-$ : nontransgenic noninoculated plant. $\mathbf{C}$, Western blot. $\mathrm{C}+$ : nontransgenic inoculated plant; $\mathrm{C}-$ : nontransgenic noninoculated plant. $\mathrm{T} 1$ to $\mathrm{T} 8$ : passionflower transformants from cv. IAC 275 (T1, T3 to T6, T8) and cv. IAC 277 (T2 and T7).
$0.11 \%$. For IAC-277, 2,730 explants were inoculated with Agrobacterium and 274 shoots were recovered. After transferring the shoots to elongation medium, 109 plantlets developed and six were identified as PCR positive for the PWV CP gene, a transformation efficiency of $0.21 \%$. These low genetic transformation efficiencies were probably related to difficulties in promoting shoot elongation and plantlet development.

Integration of PWV CP gene was confirmed by Southern blot analysis in seven of eight analyzed plants (Fig. 2A). Seven PCR-positive transgenic plants (five from IAC-275 and two from IAC-277) and the PWV CP plasmid positive control hybridized with the 850-bp PWV CP probe $(\mathrm{C}+$ ). DNA digested with BamHI revealed three transgenic plants (T1, T5, and T8) with a high number of insertional events and two plants (T2 and T7) with three insertional events. Transgenic plants T3 and T4 came from the same genetic transformation event. Transgenic passion fruit plant T6 did not show hybridization with the probe. No hybridization bands were detected on genomic DNA from nontransformed control plants (C-). Three transformants (Fig. 2B; T3, T4, and T7) expressed an RNA transcript for the PWV CP gene at a level detectable on Northern blotting. Expression of the $32-\mathrm{kDa}$ PWV CP was detected by Western blotting in two transgenic plants (Fig. 2C; T3 and T4).

Evaluation of resistance to three PWV isolates. Table 1 summarizes the evaluation of symptom development in the transgenic passion fruit plants after mechanical inoculation with PWV-SP, PWV-RJ, and PWV-CE. Fifteen days after the first inoculation, mosaic symptoms could be detected in some clones of only two transgenic plants (T3 and T7) inoculated with PWV-SP and PWV-CE, respectively. PWV symptoms could be detected in nontransgenic plants 7 to 10 days after inoculation, regardless of the inoculated virus isolate. After the second mechanical inoculation, using a double inoculum concentration, a

Table 1. Evaluation of Passion fruit woodiness virus (PWV) resistance in passion fruit transgenic plants carrying the PWV coat protein gene

\begin{tabular}{|c|c|c|c|c|c|c|c|c|c|c|}
\hline \multirow[b]{2}{*}{ Inoculum } & \multicolumn{10}{|c|}{ Transgenic plant } \\
\hline & T1 & $\mathbf{T} 2$ & T3 & T4 & T5 & T7 & T8 & $\mathrm{C}^{\mathrm{a}}$ & C & C \\
\hline \multicolumn{11}{|l|}{ PWV-SPb } \\
\hline 1st (1:200) & $0 / 4^{\mathrm{c}}$ & $0 / 7$ & $1 / 5$ & $0 / 4$ & $0 / 4$ & $0 / 2$ & $0 / 6$ & $3 / 3$ & - & - \\
\hline 2nd $(1: 100)$ & $0 / 4$ & $0 / 7$ & $3 / 5$ & $2 / 4$ & $1 / 4$ & $0 / 2$ & $0 / 6$ & - & $1 / 3$ & - \\
\hline $3 \operatorname{rd}(1: 50)$ & $4 / 4$ & $0 / 7$ & $5 / 5$ & $4 / 4$ & $4 / 4$ & $1 / 2$ & $5 / 6$ & - & - & $4 / 5$ \\
\hline \multicolumn{11}{|l|}{ PWV-RJ' } \\
\hline 1st (1:200) & $0 / 3$ & $0 / 3$ & $0 / 3$ & $0 / 4$ & $0 / 6$ & $0 / 3$ & $0 / 6$ & $1 / 3$ & - & - \\
\hline 2nd $(1: 100)$ & $1 / 3$ & $0 / 3$ & $3 / 3$ & $1 / 4$ & $5 / 6$ & $1 / 3$ & $1 / 6$ & - & $3 / 3$ & - \\
\hline $3 \mathrm{rd}(1: 50)$ & $3 / 3$ & $0 / 3$ & $3 / 3$ & $3 / 4$ & $6 / 6$ & $3 / 3$ & $6 / 6$ & - & - & $5 / 5$ \\
\hline \multicolumn{11}{|l|}{ PWV-CE ${ }^{b}$} \\
\hline 1st (1:200) & $0 / 3$ & $0 / 3$ & $0 / 3$ & $0 / 5$ & $0 / 4$ & $1 / 3$ & $0 / 8$ & $1 / 3$ & - & - \\
\hline 2nd $(1: 100)$ & $1 / 3$ & $0 / 3$ & $0 / 3$ & $1 / 5$ & $2 / 4$ & $2 / 3$ & $2 / 8$ & - & $1 / 2$ & - \\
\hline 3rd (1:50) & $3 / 3$ & $0 / 3$ & $2 / 3$ & $5 / 5$ & $4 / 4$ & $3 / 3$ & $6 / 8$ & - & - & $5 / 5$ \\
\hline
\end{tabular}

${ }^{a}$ Inoculated nontransformed plants.

${ }^{\mathrm{b}}$ PWV isolates from the states of São Paulo (PWV-SP), Rio de Janeiro (PWV-RJ), and Ceará (PWV-CE).

${ }^{c}$ Number of symptomatic plants/number of inoculated plants. 
variable level of resistance among the transgenics was observed. Clones of two transgenic plants of IAC-275 (T1 and T7) and two of IAC-277 (T2 and T8) did not show any symptoms when inoculated with PWV-SP, from which the CP gene was cloned. For the other two PWV isolates, under the same conditions, only the clones of transgenic plant T2 (IAC-277) did not develop symptoms. Again, some nontransgenic plants inoculated with all isolates showed symptoms 7 to 10 days after inoculation. Under higher inoculation pressure (third inoculation), only clones of the transgenic plant T2 behaved as highly resistant to infection with all three isolates of PWV. Almost 100\% of nontransgenic plants used as controls were susceptible to infection with PWV isolates. Plants of T2 clones, derived from stem cuttings of the primary transformant, were observed for more than 60 days, and no symptoms were noticed (Fig. 3).

\section{DISCUSSION}

Passion fruit woodiness is a global problem, and for the last decade it has been the major limiting disease in several passion fruit producing states in Brazil. Since there is no natural resistance to PWV among the available yellow passionflower accessions, the successful production of PWV CPtransgenic passionflower resistant to $\mathrm{PWV}$ may provide a viable alternative for disease control.

Expression of potyvirus $\mathrm{CP}$ gene sequences in transgenic plants is a wellestablished and effective strategy to protect plants from potyvirus infection $(2,10,13$, 22,23). When Nicotiana benthamiana was transformed with the $\mathrm{CP}$ gene of a Taiwanese isolate of PWV, it showed complete resistance to $\mathrm{PWV}$ when challenged with different concentrations of the virus (27).

In the present work, seven plants were confirmed to contain the PWV CP gene by Southern blot analyses. Clones of all transgenic plants showed some resistance to infection under low inoculum pressure, but only $\mathrm{T} 2$ plants were highly resistant or immune when the inoculation pressure was increased. These transgenic plants also exhibited a broad-spectrum resistance to infection by the three PWV isolates tested. Alfenas et al. (1) recently reported the development of transgenic passion fruit carrying the $3^{\prime}$ region of the $N i b$ gene and the $5^{\prime}$ region of the $\mathrm{CP}$ gene of an isolate of CABMV from the state of Minas Gerais, Brazil (MG1). In that study, however, the resistance of the transgenic plant was isolate-specific. One transgenic passion fruit plant (TE5-10) was resistant to CABMV-MG1 but susceptible to an isolate from the state of Pernambuco, Brazil (PE1). Transgenic papaya line 55-1, transformed with the $\mathrm{CP}$ gene of a mild strain of Papaya ringspot virus from Hawaii (PRSV HA 5-1), was also resistant to the local Hawaii strain but susceptible to 12 isolates of PRSV from different areas of the world (24). Further studies, however, showed that one transgenic papaya line (19-0-1) carrying the CP gene of a severe PRSV strain from Taiwan (PRSV YK) was immune not only to the homologous strain (YK) but also to three heterologous strains from Hawaii, Thailand, and Mexico. These strains share more than $89 \%$ identity with the YK strain, for both the CP coding region and the 3'NTR (2).

The only highly resistant or immune transgenic passion fruit plants (T2) obtained in the present work include three insertional events of the transgene. However, results of the present work also showed that multiple insertional events of the transgene alone were not sufficient to confer resistance or immunity to PWV. Transgenic plants $\mathrm{T} 1, \mathrm{~T} 5$, and $\mathrm{T} 8$, which showed higher numbers of transgene insertional events than $\mathrm{T} 2$, were all susceptible to infection under high inoculum pressure. These plants did not show any delay in either expression of symptoms or recovery from symptoms after further growth. Recent studies with transgenic peanut plants carrying the $\mathrm{CP}$ gene sequence of Peanut stripe virus (PStV), which is a strain of
Bean common mosaic virus, also did not find correlation between transgene insertional events and resistant or immune phenotypes of the transformed plants (10). Transgenic plants T3 and T4, which came from the same transformation event, expressed high levels of the PWV CP in Western blotting but were susceptible to infection with PWV isolates, confirming that, in this system, protein expression is not related to resistance.

Studies of pathogen-derived resistance (PDR) to virus infection have shown that the resistance mechanism may be either based on the expression of the transgeneencoded protein or RNA-mediated. The first type of PDR became known as coat protein-mediated resistance, whereas the second is now referred to as RNA silencing or RNA interference (RNAi) (14). The presence of multiple copies of a transgene has been associated with RNA-mediated resistance, which has been linked to immunity and high levels of resistance to infection $(9,14)$. CP transcription and expression was either suppressed or silenced in the $\mathrm{T} 2$ transgenic passion fruit plants, since no transcribed RNA was detected by Northern and Western blotting, suggesting
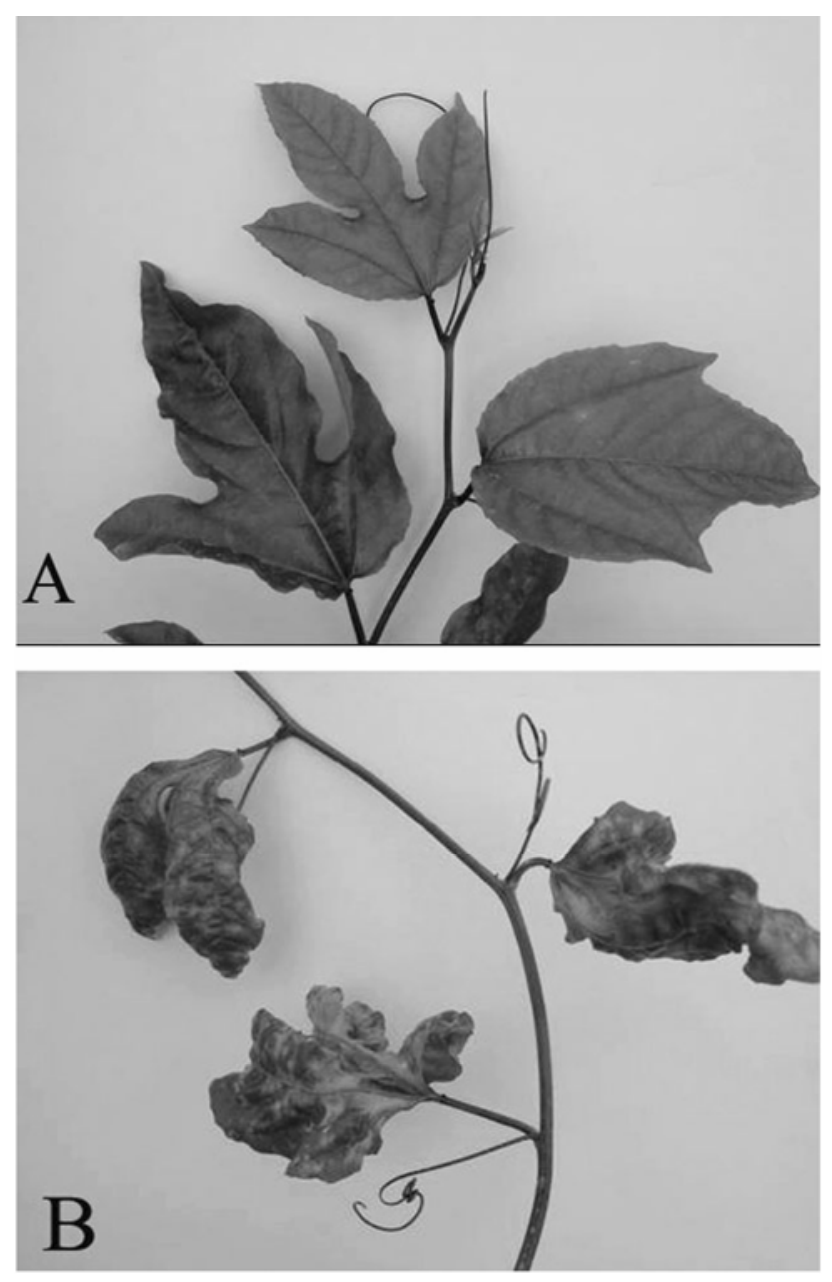

Fig. 3. A, Asymptomatic upper leaves of $\mathrm{T} 2$ transgenic plant after three mechanical inoculation with São Paulo isolate of Passion fruit woodiness virus (PWV-SP). B, nontransgenic plant showing symptoms of PWV-SP. 
that RNAi might be the mechanism responsible for the high resistance or immunity of T2 plants to all three isolates of PWV.

The present work indicates that the immune T2 plants are less strain-specific and may provide more substantial control of PWV than other transformants in different geographic regions of Brazil. This transgenic line is currently being vegetatively propagated for further analysis. Plants will be mechanically inoculated with isolates of PWV from other regions of the country, as well as with viruliferous aphids, which represent the natural way PWV is transmitted in the field. Furthermore, T2 plants will also be self crossed or crossed with progenitors of cultivar IAC-277 to generate a homozygous line. Transgenic plants will be further evaluated under natural spread of PWV in pilot field experiments.

\section{ACKNOWLEDGMENTS}

We are grateful to Fundação de Amparo à Pesquisa no Estado de São Paulo (FAPESP) for financial support (Grant No. 2001/14481-3).

\section{LITERATURE CITED}

1. Alfenas, P. F., Braz, A. S. K., Torres, L. B., Santana, E., Nascimento, V. S., Carvalho, M. G., Otoni, W. C., and Zerbini, F. M. 2005. Transgenic passion fruit expressing RNA derived from Cowpea aphid-borne mosaic virus is resistant to passion fruit woodiness disease. Fitopatol. Bras. 30:33-38.

2. Bau, H.-J., Cheng, Y.-H., Yu, T.-A., Yang, J.-S., and Yeh, S.-D. 2003. Broad-spectrum resistance to different geographic strains of Papaya ringspot virus in coat protein gene transgenic papaya. Phytopathology 93:112-120.

3. Chagas, C. M., Kitajima, E. W., Lin, M. T., Gama, M. I. C. S., and Yamashiro, T. 1981. Grave moléstia em maracujá amarelo (Passiflora edulis f. flavicarpa) no Estado da Bahia, causado por um isolado do vírus do "woodiness" do maracujá. Fitopatol. Bras. 6:259-268.

4. Docampo, D. M., and Lenardón, S. L. 1999. Métodos para detectar patógenos sistêmicos. INTA-JICA, Córdoba, Argentina.

5. Doyle, J. J. T., and Doyle, J. L. 1990. Isolation of plant DNA from fresh tissue. Focus 12:13-18.

6. Fauquet, C. M., Mayo, M. A., Maniloff, J.,
Desselberger, U., and Ball, L. A. 2005. Virus Taxonomy: Classification and Nomenclature of Viruses. Eighth Report of the International Committee on Taxonomy of Viruses. Elsevier, Academic Press, London.

7. Ferreira, S. A., Pit, K. Y., Manshardt, R., Zee, F., Fitch, M., and Gonsalves, D. 2002. Virus coat protein transgenic papaya provides practical control of Papaya ringspot virus in Hawaii. Plant Dis. 86:101-105.

8. Gioria, R., Bosque, G. G., Rezende, J. A. M., Amorim, L., and Kitajima, E. W. 2000. Incidência de viroses de maracujazeiro na Alta Paulista - SP e danos causados pelo "Passion fruit woodiness virus". Fitopatol. Bras. 25:182189.

9. Goodwin, J., Chapman, K., Swaney, S., Parks, T. D., Wernsman, E. A., and Dougherty, W. G. 1996. Genetic and biochemical dissection of transgenic RNA-mediated virus resistance. Plant Cell 8:95-105.

10. Higgins, C. M., Hall, R. M., Mitter, N., Cruickshank, A., and Dietzgen, R. G. 2004. Peanut stripe potyvirus resistance in peanut (Arachis hypogaea L.) plants carrying viral coat protein gene sequences. Transgen. Res. 13:59-67.

11. Lacorte, C., and Romano, E. 1998. Transferência de vetores para Agrobacterium. Pages 93109 in: Manual de Transformação Genética de Plantas. A. C. M. Brasileiro and V. T. C. Carneiro, eds. Embrapa, Brasília.

12. Laemmli, U. K. 1970. Cleavage of structural proteins during the assembly of the head of bacteriophage T-4. Nature 227:680-685.

13. Lindbo, J. A., and Dougherty, W. G. 1992. Pathogen-derived resistance to a potyvirus: Immune and resistant phenotypes in transgenic tobacco expressing altered forms of a potyvirus coat protein nucleotide sequence. Mol. Plant-Microbe Interact. 5:144-153.

14. Lindbo, J. A., and Dougherty, W. G. 2005. Plant pathology and RNAi: a brief history. Annu. Rev. Phytopathol. 43:191-204.

15. Monteiro, A. C. B. A., Higashi, E. N., Gonçalves, A. N., and Rodriguez, A. P. M. 2000. A novel approach for the inorganic medium components for micropropagation of yellow passion fruit (Passiflora edulis Sims. f. flavicarpa Deg.). In Vitro Cell. Dev. Biol.: Plant 36:527-531.

16. Murashige, T., and Skoog, F. 1962. A revised medium for rapid growth and bioassays with tobacco tissue cultures. Physiol. Plant. 15:473497.

17. Nascimento, A. V. S., Souza, A. R. R., Alfenas, P. F., Andrade, G. P., Carvalho, M. G., Pio-
Ribeiro, G., and Zerbini, F. M. 2004. Análise filogenética de potyvirus causando endurecimento dos frutos do maracujazeiro no Nordeste do Brasil. Fitopatol. Bras. 29:378-383.

18. Novaes, Q. S., and Rezende, J. A. M. 2003. Selected mild strains of Passion fruit woodiness virus (PWV) fail to protect preimmunized vines in Brazil. Sci. Agric. 60:699708.

19. Ritzenthaler, C. 2005. Resistance to plant viruses: Old issue, news answers? Curr. Opin Biotechnol. 16:1-5.

20. Sanford, J. C., and Johnston, S. A. 1985. The concept of parasite-derived resistance - Deriving resistance genes from the parasite's own genome. J. Theor. Biol. 113:395-405.

21. Santana, E. N., Braz, A. S. K., Torres, L. B., Zambolim, E. M., and Zerbini, F. M. 1999. Molecular characterization of Potyvirus isolates causing passion fruit woodiness in Brazil Virus Rev. Res. 47:153.

22. Smith, H. A., Powers, H., Swaney, S., Brown C., and Dougherty, W. G. 1995. Transgenic potato virus $\mathrm{Y}$ resistance in potato: Evidence for an RNA-mediated cellular response. Phytopathology 85:864-870.

23. Sonoda, S., Mori, M., and Nishiguchi, M. 1999. Homology-dependent virus resistance in transgenic plants with the coat protein gene of sweet potato feathery mottle potyvirus: Target specificity and transgene methylation. Phytopathology 89:385-391.

24. Tennant, P. F., Gonsalves, C., Ling, K.-S., Fitch, M., Manshardt, R., Slightom, J. L., and Gonsalves, D. 1994. Differential protection against papaya ringspot virus isolates in coat protein gene transgenic papaya and classically cross-protected papaya. Phytopathology 84:1359-1366.

25. Tepfer, M. 2002. Risk assessment of virusresistant transgenic plants. Annu. Rev. Phytopathol. 40:467-491.

26. Tricoli, D. M., Carney, K. J., Russell, P. F., McMaster, J. R., Groff1, D. W., Hadden, K. C. Himmel, P. T., Hubbard, J. P., Boeshore, M. L. and Quemada, H. D. 1995. Field evaluation of transgenic squash containing single or multiple virus coat protein gene constructs for resistance to cucumber mosaic virus, watermelon mosaic virus 2, and zucchini yellow mosaic virus. Bio/Technology 13:1458-1465.

27. Yeh, S. D., and Chu, F. H. 1996. Production and evaluation of transgenic tobacco plants expressing the coat protein gene of passion fruit woodiness virus. Bot. Bull. Acad. Sin. 37:181-190. 